\title{
Intelligent Control of a Photovoltaic Pumping System
}

\author{
Abdessamia Elgharbi \\ Physics Department, \\ University of Tunis El Manar, \\ Tunis, Tunisia \\ abdogharbi@yahoo.fr
}

\author{
Dhafer Mezghani \\ Physics Department, \\ University of Tunis El Manar, \\ Tunis, Tunisia \\ dhafer.mezghanni@gmail.com
}

\author{
Abdelkader Mami \\ Physics Department, \\ University of Tunis El Manar, \\ Tunis, Tunisia \\ abdelkader.mami@fst.utm.tn
}

\begin{abstract}
This paper presents the application of the Adaptive Neuro Fuzzy Inference System (ANFIS) to track the maximum power of a photovoltaic generator that feeds a motor-pump group unit through a Pulse Width Modulation (PWM) inverter powered by a Single Ended Primary Inductance Converter (SEPIC) installed in the laboratory. The ANFIS control is trained in different temperatures and irradiances and the maximum power point tracking system varies automatically the duty cycle of the SEPIC converter. The performance of the MPPT controller is tested in simulations in Matlab/Simulink.
\end{abstract}

\section{Keywords-PV pumping system; MPPT; SEPIC; ANFIS}

\section{INTRODUCTION}

In photovoltaic (PV) systems, sunlight is converted into DC electricity. From the PV module we get low voltage, so we have to increase this voltage using an SEPIC converter. The MPPT of the PV system using SEPIC converter is controlled by intelligent controllers, in our case the developed Adaptive Neuro Fuzzy Inference System (ANFIS) model. This paper addresses the above problem and presents the ANFIS method used as the MPPT algorithm from which are many presented in previous papers [1]. Many papers focused on the comparison of the ANFIS with some other Artificial Intelligence (AI) methods such as Neural Networks (NNs), Fuzzy Logic (FL) and proved that ANFIS is the most suitable for use in uncertain systems [2] and without a doubt presented ANFIS as the most suitable algorithm for MPP tracking.

\section{PhOtOVOLTAIC PUMPING SYSTEM}

Photovoltaic conversion is produced by exposing the solar cell to sunlight. The received energy causes disordered movement of the electrons within the material. The current collection is done by the metal contacts (electrodes). If these electrodes are connected to an external circuit, a direct current flows. In a PV generator a number of solar cells are assembled to form a PV module. In our case we combined four Kaneka GSA 60 (60Watt) PV panels connected in series delivering enough power for the system, a Single Ended Primary Inductance Converter (SEPIC) and a motor pump EBARA as shown in Figure 1. The induction motor pump is supplied from the PV generator whose volt/ampere characteristics depend nonlinearly on solar insulation, temperature variations and on the current drawn by the motor-pump [3]. The PV generator behavior is equivalent to a current source shunted by a junction diode, if we neglect the physical phenomena of PV cell such as contact resistance, current lost by photocell sides and the age of cells [4-6]. The PV panel operation can be described using a complete physical mathematical model as shown in Figure 2 and described by (1)-(3) [7-10].

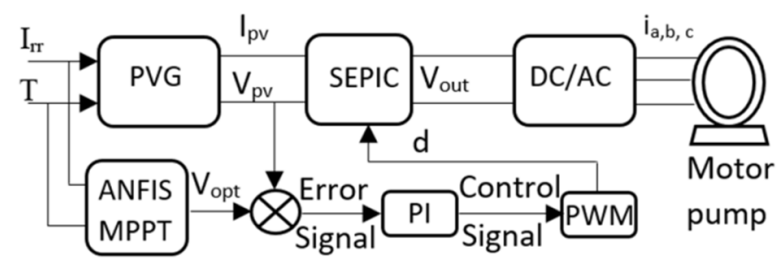

Fig. 1. Synoptic diagram of the pumping structure

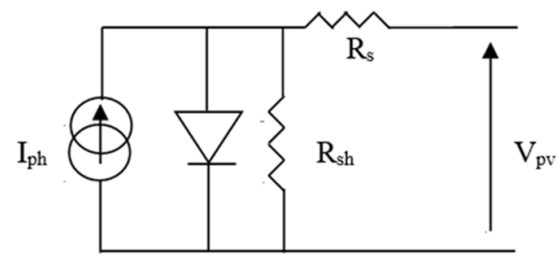

Fig. 2. Electrical scheme of PV module

$$
\begin{gathered}
I_{p v}=I_{p h}-\frac{I_{0}\left\{\exp \left[q\left(v_{p v}+R_{s} I_{p v}\right)\right]-1\right\}}{n_{i} K T_{p}}-\left(v_{p v}+R_{s} I_{p v}\right) R_{s h} \\
I_{p h}=\frac{\left[I_{c c}+K_{i s c}\left(T-T_{r e f}\right) E_{c}\right.}{E_{c r e f}} \\
T=\frac{(N O C T-20) E_{c}}{800}+T_{a}
\end{gathered}
$$

where $\mathrm{E}_{\mathrm{c}}$ is the solar illumination $\left(\mathrm{W} / \mathrm{m}^{2}\right), \mathrm{E}_{\text {cref }}$ is the reference illumination $\left(1000 \mathrm{~W} / \mathrm{m}^{2}\right), \mathrm{T}_{\mathrm{a}}$ is the ambient temperature $\left({ }^{\circ} \mathrm{C}\right)$, $\mathrm{T}_{\text {ref }}$ is the reference ambient temperature $\left(25^{\circ} \mathrm{C}\right), \mathrm{T}$ is the surface temperature of the PV generator $\left({ }^{\circ} \mathrm{C}\right.$ or $\left.{ }^{\circ} \mathrm{K}\right), \mathrm{I}_{\mathrm{cc}}$ is the total short-circuit current for the state reference $(\mathrm{A}), \mathrm{K}_{\mathrm{isc}}$ is the short-circuit -temperature current coefficient $\left(0.0017 \mathrm{~A} /{ }^{\circ} \mathrm{C}\right), \mathrm{I}_{\mathrm{s}}$ is the opposite total current of the PV generator (A), $\mathrm{K}$ is the Boltzmann constant $\left(1.38 .10^{-23} \mathrm{j} /{ }^{\circ} \mathrm{K}\right), \mathrm{q}$ is the electron charge $\left(1.6 .10^{-19} \mathrm{C}\right)$ and NOCT the nominal operating temperature $45^{\circ}$.

\section{SEPIC}

The SEPIC exchanges energy between the capacitors and inductors in order to convert the voltage from input to the output. The amount of energy exchanged is controlled by a switch, which is typically a transistor such as a MOSFET. The 
output voltage depends on the duty cycle applied to the switch [3]. It can be higher or lower than the input voltage.

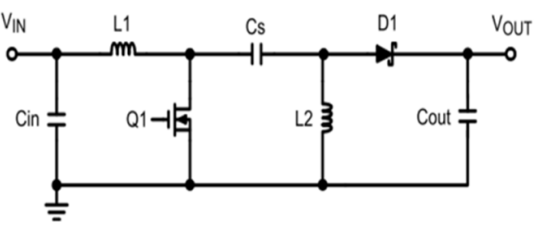

Fig. 3. SEPIC converter topology

If we apply the Kirchhoff's voltage law in continuous conduction mode, the duty cycle will be given by [15]:

$$
D=\frac{\left(v_{\text {out }}+v_{d}\right)}{\left(v_{\text {out }}+v_{\text {in }}+v_{d}\right)}
$$

where $V_{\text {in }}$ is the input voltage, $V_{\text {out }}$ is the output voltage and $V_{d}$ is the threshold voltage of the diode. For the desired output, the variation of the duty cycle will depend on the input voltage. The parameters of the SEPIC converter used in this work were developed in a previous study [12].
TABLE I. SEPIC PARAMETERS

\begin{tabular}{|c|c|}
\hline Parameter & Value \\
\hline Input Voltage, $\mathrm{V}_{\text {in }}$ & $300 \mathrm{~V}$ \\
\hline Output Voltage, $\mathrm{V}_{\text {out }}$ & $310 \mathrm{~V}$ \\
\hline Outut current, $\mathrm{I}_{\mathrm{o}}$ & $1.19 \mathrm{~A}$ \\
\hline Switching frequency, $\mathrm{f}_{\text {sw }}$ & $5 \mathrm{KHZ}$ \\
\hline Duty cycle, $\mathrm{D}$ & 0.508 \\
\hline $\mathrm{L} 1$ & $60 \mathrm{mH}$ \\
\hline $\mathrm{L} 2$ & $60 \mathrm{mH}$ \\
\hline $\mathrm{Cs}$ & $100 \mu \mathrm{F}$ \\
\hline Cin & $2000 \mu \mathrm{F}$ \\
\hline Cout & $2000 \mu \mathrm{F}$ \\
\hline Inductor Selection $\Delta \mathrm{I}_{\mathrm{l}}$ & $0.491 \mathrm{~A}$ \\
\hline
\end{tabular}

\section{MPPT CONTROL USING ANFIS ALGORITHM}

In this part, a robust control of MPPT using ANFIS will be presented which have been developed in Matlab/Simulink. It consists of the PV generator with MPPT control, an SEPIC converter, a voltage source inverter controlled by pulse width modulation strategy [13] and a motor pump unit as shown in the Simulink model in Figure 4.

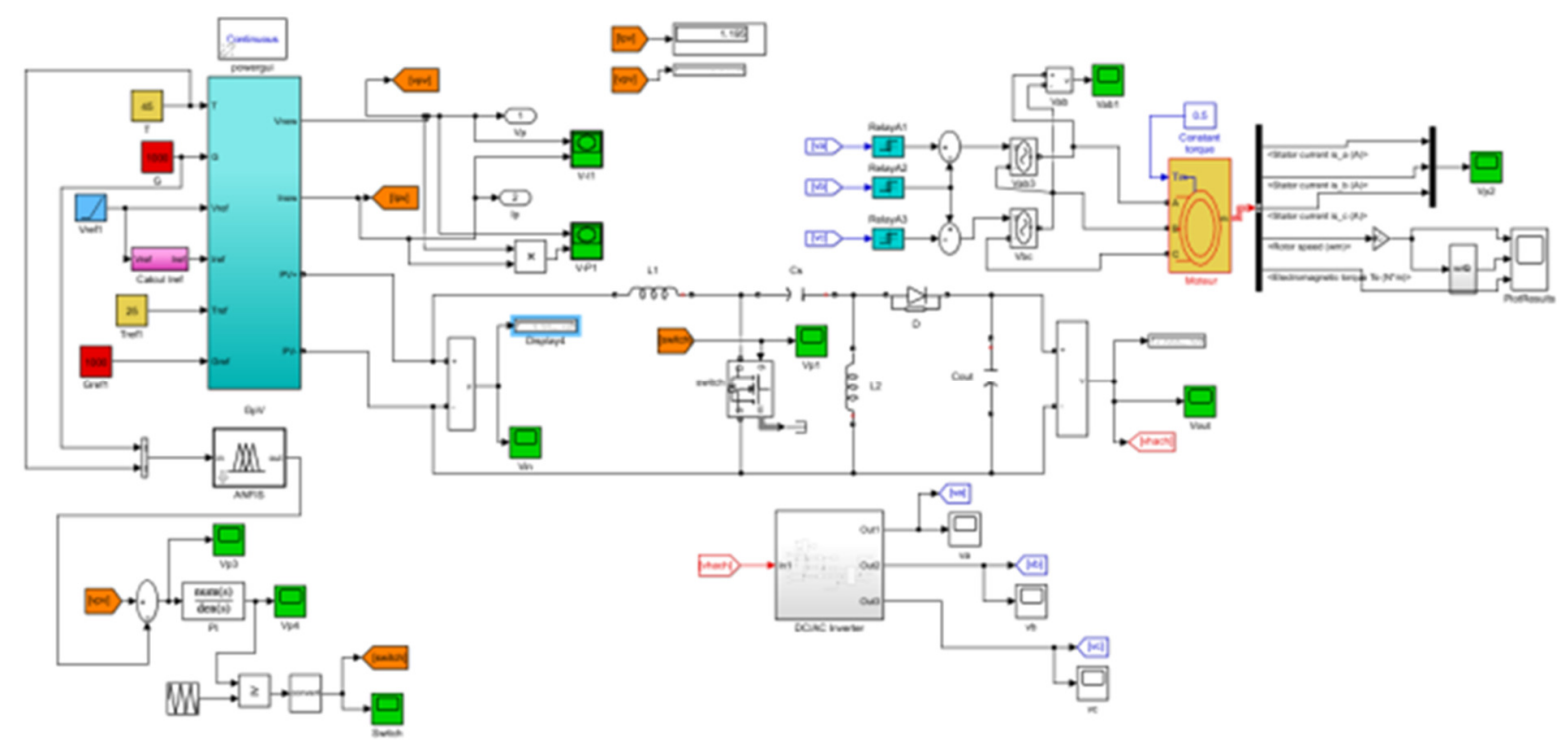

Fig. 4. Simulink model of the proposed PV pumping system.

The explanation for creating and the levels comprising the ANFIS cognitive method are described in $[12,13]$. In this proposed method the photovoltaic system uses a MPPT control using ANFIS algorithm which automatically varies the duty cycle of the SEPIC in order to generate the required voltage to extract maximum power. The data input for the ANFIS is irradiance and temperature and the Output is the optimal voltage of the PV generator $\mathrm{V}_{\text {popt. }}$ Two voltages are compared and the error is given to a proportional integral (PI) controller, to generate control signals. The control signal generated by the PI controller is given to the PWM generator. The generated PWM signal that controls the duty cycle of the SEPIC converter in order to adjust the operating point of the PV module is shown in Figure 5.

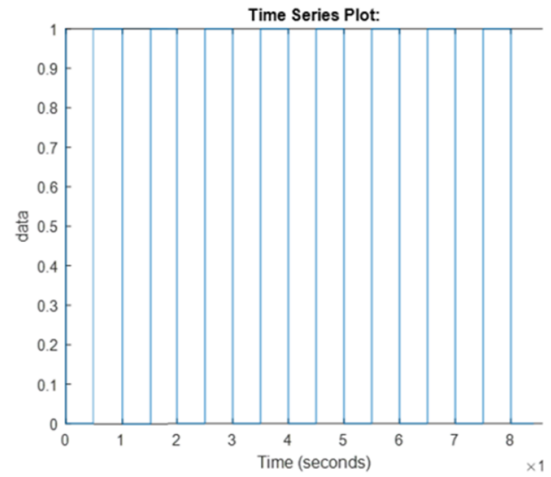

Fig. 5. The generated PWM signal of the SEPIC 
By training the ANFIS with a sufficient number of epochs, and adjusting the values of membership function, it generates a set of fuzzy rules in order to produce the appropriate output for different input values. The Simulink model of PV module generates the training data set for ANFIS by varying the operating temperature from $25^{\circ} \mathrm{C}$ to $45^{\circ} \mathrm{C}$ in steps of $10^{\circ} \mathrm{C}$ and the solar irradiance level from $200 \mathrm{~W} / \mathrm{m}^{2}$ to $1000 \mathrm{~W} / \mathrm{m}^{2}$ in steps of $100 \mathrm{~W} / \mathrm{m}^{2}$. For each pair of operating temperature and solar irradiance, the optimal voltage of PV module is recorded. Thus, in total 45 training data sets and 100 epochs were used to train the ANFIS model. ANFIS constructs a fuzzy inference system (FIS) by using input/output data sets and the membership function parameters of FIS are tuned using the hybrid optimization method which is a combination of least-squares and back propagation algorithm. ANFIS is a Takagi Sugeno network within the adaptive systems facilitating learning and training. Figure 7 presents the ANFIS structure developed by the Matlab code. ANFIS controller works according to the input values of temperature $\left({ }^{\circ} \mathrm{C}\right)$ and sun illumination $\left(\mathrm{W} / \mathrm{m}^{2}\right)$ based on the trained .fis file. As we can see in Figure7, this is a five-layer network with two inputs and one output. Each input parameter has five membership functions which are learned by the ANFIS method. According to input-output mapping of data sets, twenty-five fuzzy rules are derived. A 3-dimentional plot between temperature, irradiance and optimal voltage presenting the surface generated by the ANFIS is shown in Figure 8.

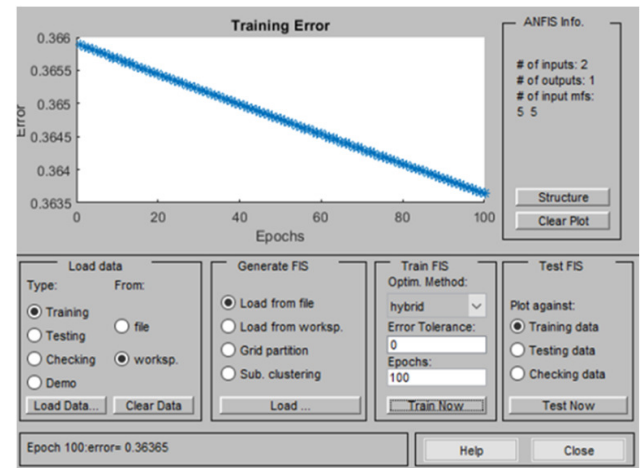

Fig. 6. Neuro fuzzy designer

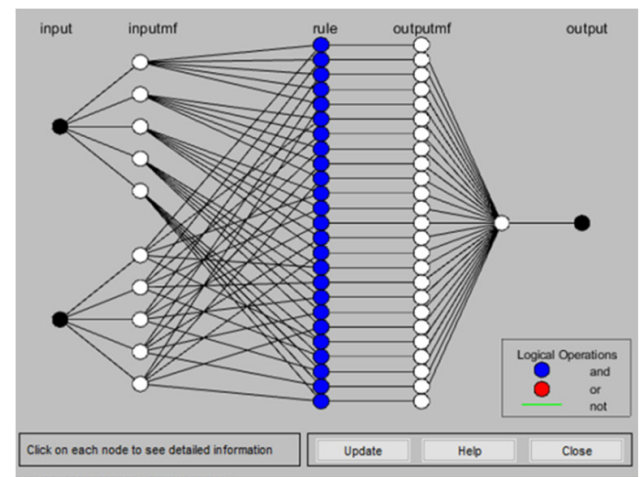

Fig. 7. ANFIS controller structure

The ANFIS surface depicts that the maximum available power point of solar PV module increases with increase in irradiance and moderate temperature which verifies the non- linear behavior of the PV module. Having obtained the right value $V_{\text {opt }}$ output of the ANFIS, the error between $V_{\text {opt }}$ and $V_{p v}$ will be entered into the PI block to generate the control signal of the PWM block and thus the PWM duty cycle of the SEPIC converter is created.

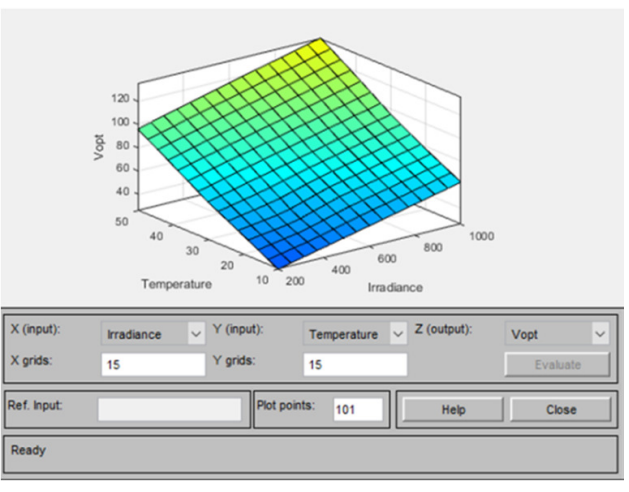

Fig. 8. Surface between the inputs and the output

\section{Simulation RESUlts}

The results were obtained using MATLAB/Simulink to perform simulation. Figures $9-10$ present the $\mathrm{P}-\mathrm{V}$ and $\mathrm{I}-\mathrm{V}$ characteristics with different values of irradiance and temperature.

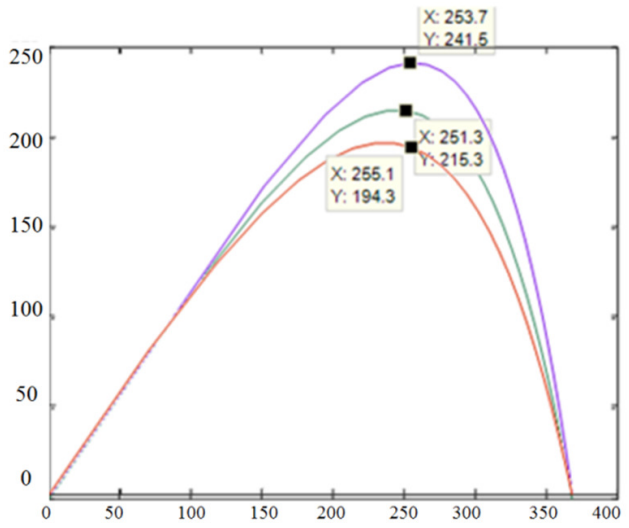

Fig. 9. $\mathrm{P}-\mathrm{V}$ characteristics in different temperatures

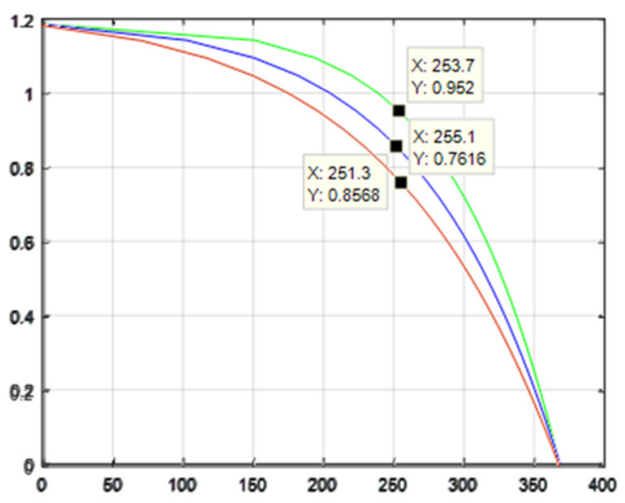

Fig. 10. I-V characteristics in different temperatures 


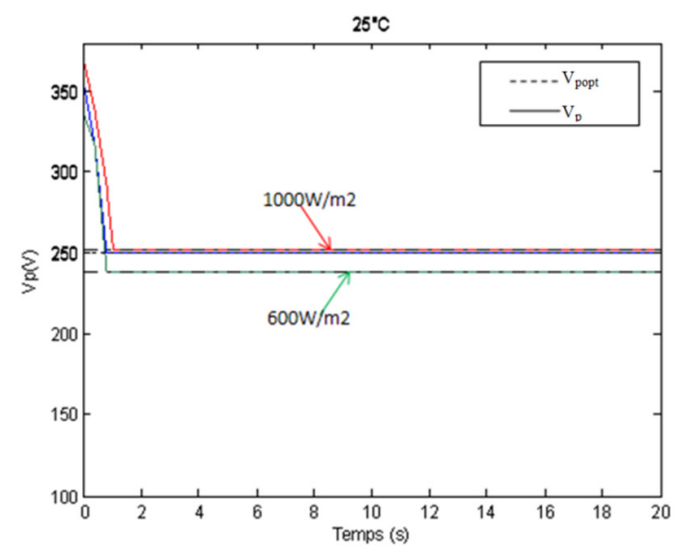

Fig. 11. Panel voltage $\left(V_{p}\right)$ characteristic for different values of irradiance

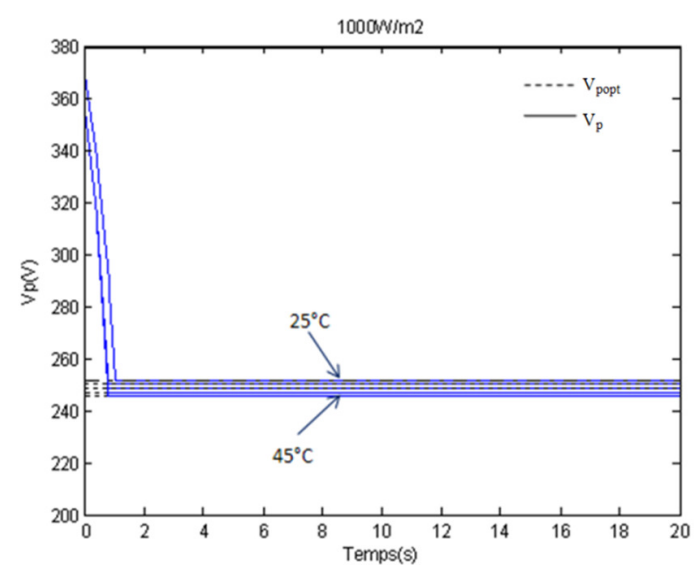

Fig. 12. Panel voltage $\left(V_{p}\right)$ characteristic for different values of temperature

Note that the voltage $V_{p}$ of the PV generator shown in Figures 11-12 follows a linear curve over time, and any increase in illumination is accompanied by an increase in the optimal voltage $V_{\text {popt. Figures 13-14 present the output optimal }}$ voltage $\left(\mathrm{V}_{\text {popt }}\right)$ of the ANFIS maximum power point tracking at $25^{\circ} \mathrm{C}$ for different illumination values.

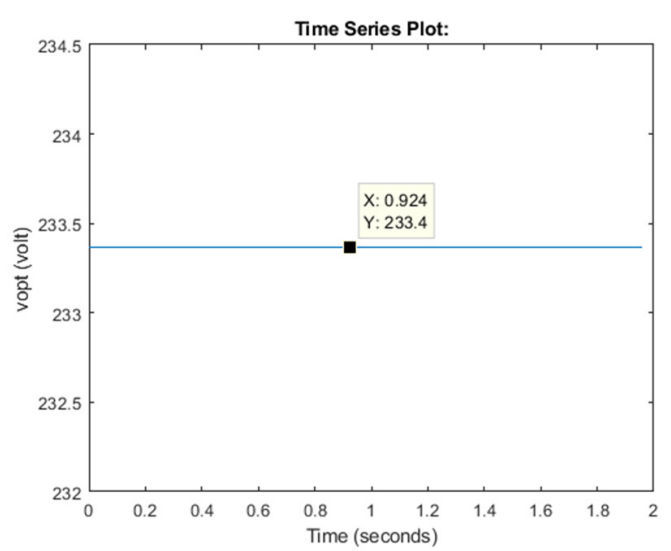

Fig. 13. $\mathrm{V}_{\text {popt }}$ of the ANFIS maximum power point tracking in $600 \mathrm{~W} / \mathrm{m}^{2}$

In Figures 15-16 we see the $\mathrm{V}_{\text {popt }}$ of the ANFIS maximum power point tracking at $1000 \mathrm{~W} / \mathrm{m}^{2}$ for different temperature values. A fast continuation of the evolution of the PV voltage is observed, as well as for current and electrical power with respect to their optimal values related to the variation of climatic conditions.

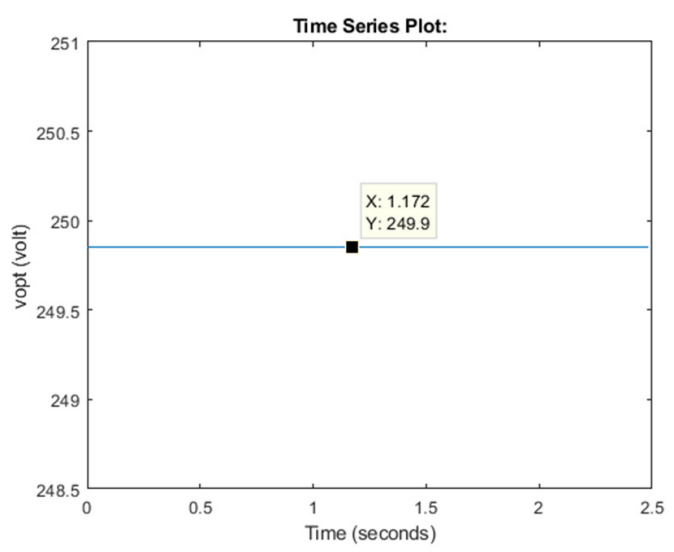

Fig. 14. $\mathrm{V}_{\text {popt }}$ of the ANFIS maximum power point tracking in $800 \mathrm{~W} / \mathrm{m}^{2}$

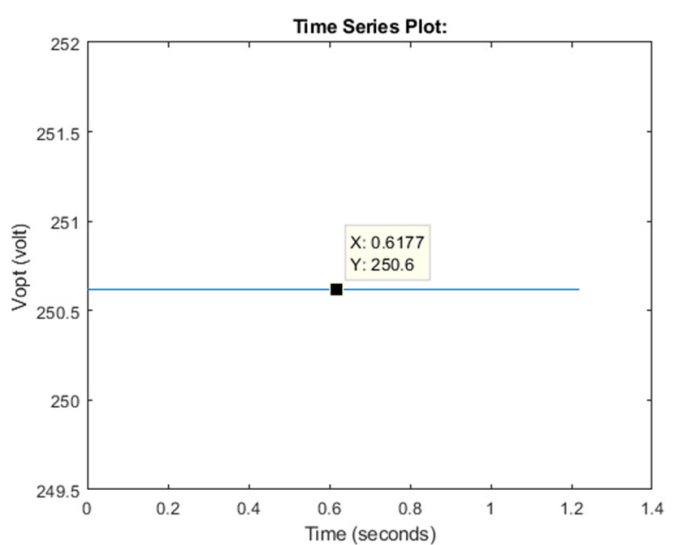

Fig. 15. $\mathrm{V}_{\text {popt }}$ of the ANFIS maximum power point tracking in $25^{\circ} \mathrm{C}$

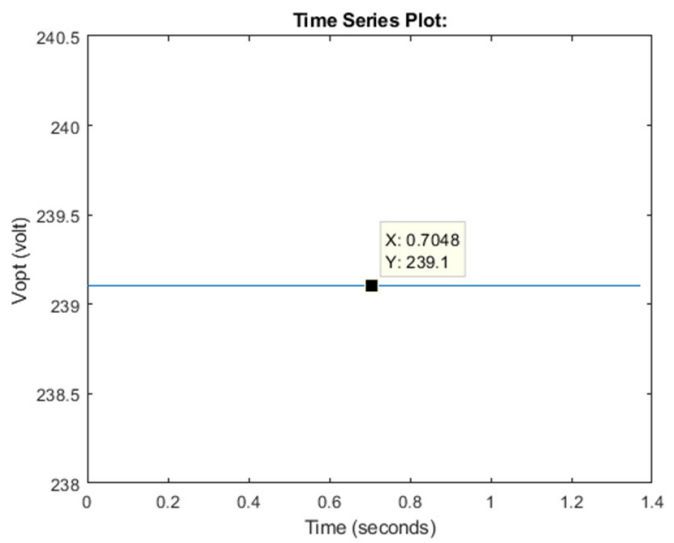

Fig. 16. $\mathrm{V}_{\text {popt }}$ of the ANFIS maximum power point tracking in $45^{\circ} \mathrm{C}$

The application of the SEPIC converter allows the generator to follow its MPPT and to provide the required operation voltage of the voltage source inverter for maximum efficiency. The output voltage of the ANFIS controller 
produces very high efficiency and stability for different irradiance and temperature scenarios. The results in Figures 1719 illustrate the output voltage of the SEPIC for $1000 \mathrm{~W} / \mathrm{m}^{2}$ of illumination for different values of temperature.

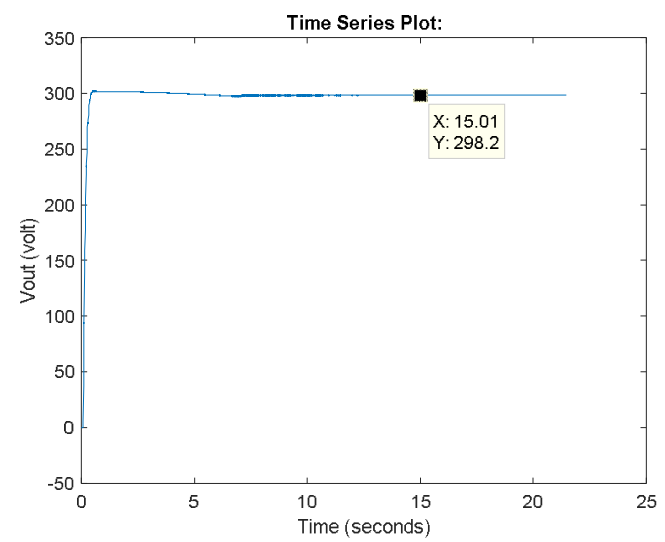

Fig. 17. Output voltage (Vout) of the SEPIC converter in $45^{\circ} \mathrm{C}$

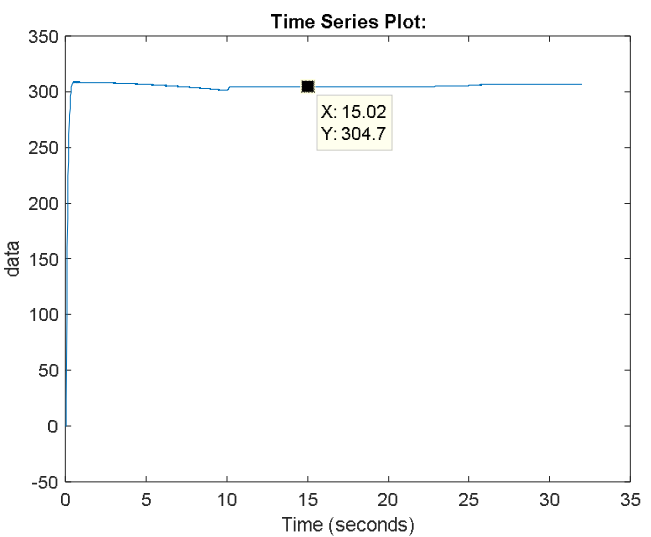

Fig. 18. Vout of the SEPIC in $30^{\circ} \mathrm{C}$

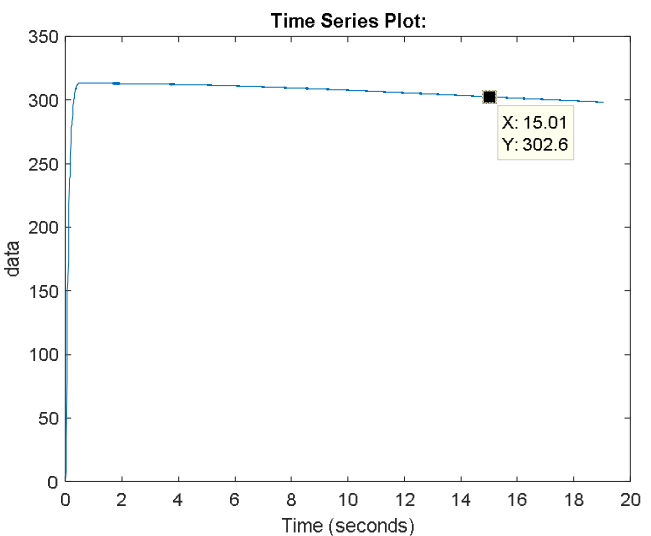

Fig. 19. Vout of the SEPIC in $20^{\circ} \mathrm{C}$

The time evolution of the composed voltages in the output voltage inverter is presented in Figure 20, the average model of the wave generated by the PWM voltage inverter subsequently allows obtaining a constant motor torque. The simulation speed of motor-pump and the water flow at $45^{\circ} \mathrm{C}$ for different illumination levels $\left(600,800,1000 \mathrm{~W} / \mathrm{m}^{2}\right)$ is shown consecutively in Figures 21 and 22. We note that using the ANFIS command, the speed of rotation of the motor-pump set has increased with the illumination to reach 2834rpm, which affects the water flow, which in turn evolved from $27.45 \mathrm{~L} / \mathrm{min}$ to $34 \mathrm{~L} / \mathrm{min}$. By examining the temporal evolutions of the voltage of the photovoltaic panel $V_{p}$ and the speed of rotation of the motor pump shaft, we observe that in steady state these variables are constant over time for varying input parameters.

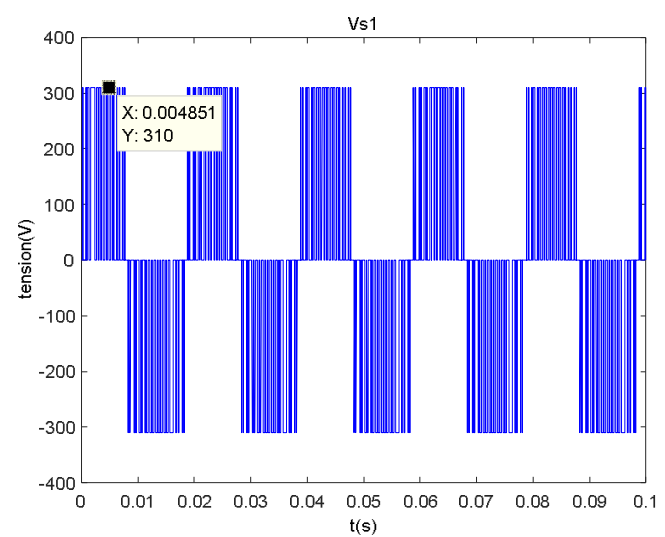

Fig. 20. Output phase voltage (Vs1) of the DC-AC inverter

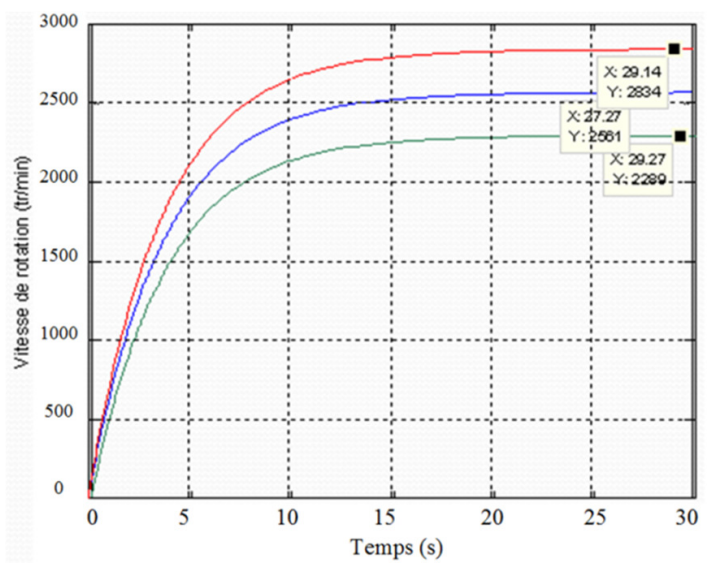

Fig. 21. Speed of the motor-pump for different illuminations

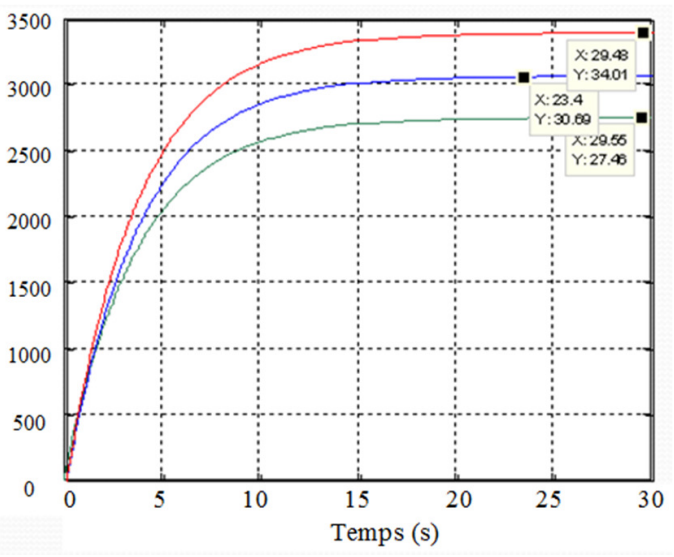

Fig. 22. Time variation of the water flow $(\mathrm{L} / \mathrm{min})$ 
In Figures 23-24 we present the electromagnetic couple (Cem) in temperature of $45^{\circ} \mathrm{C}$ and different values of illumination which varies from $600 \mathrm{~W} / \mathrm{m}^{2}$ to $1000 \mathrm{~W} / \mathrm{m}^{2}$.

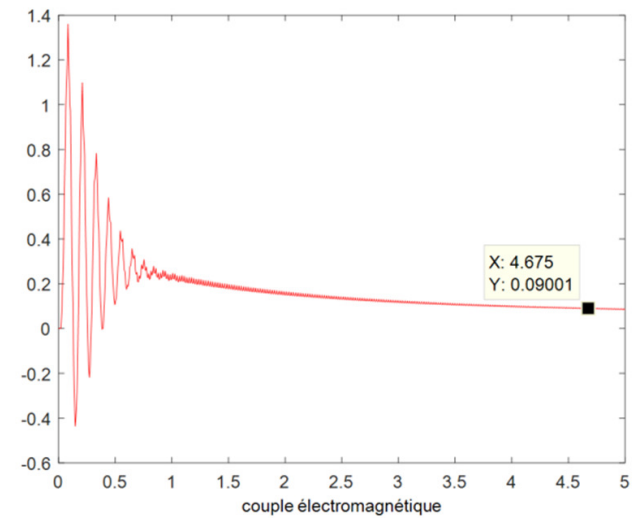

Fig. 23. The electromagnetic couple (Cem) in $800 \mathrm{~W} / \mathrm{m}^{2}$

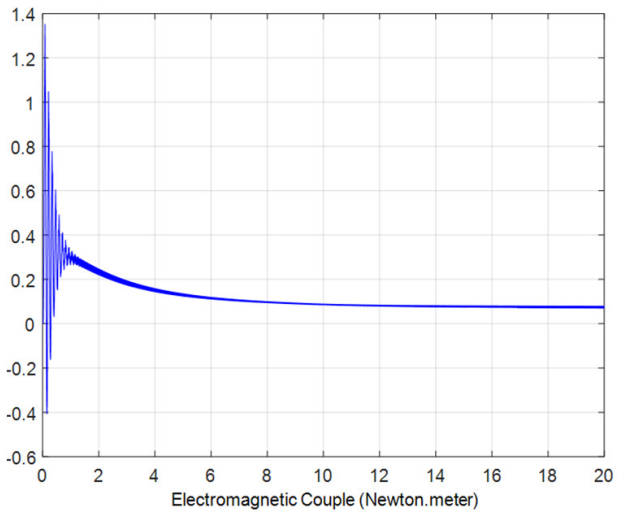

Fig. 24. The Cem in $1000 \mathrm{~W} / \mathrm{m}^{2}$

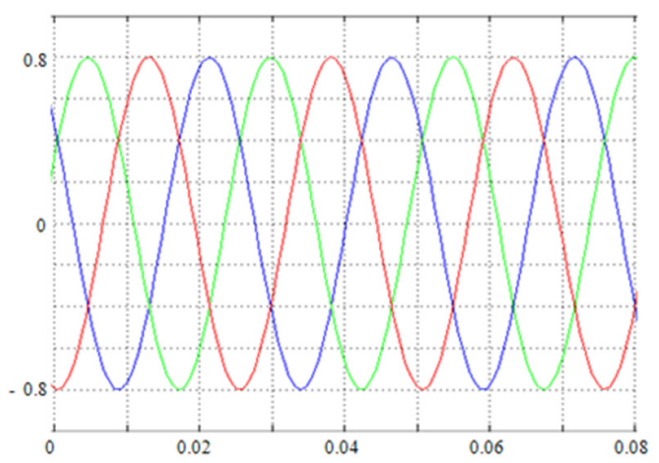

Fig. 25. The statoric currents of the motor-pump

\section{CONCLUSION AND OUTLOOK}

Based on the simulation results we conclude that the predefined control objectives were achieved. The maximum power point tracking control of the PV pumping system using ANFIS based SEPIC was presented in this paper. For each considered illumination and temperature the optimal voltage was reached using ANFIS maximum power point tracking method. The robustness of this intelligent control system was tested in load changes, and the influence of fluctuating solar radiation on the dynamics was investigated. As future research, it is possible to implement an artificial intelligence technique to control the hybrid sources (photovoltaic and wind).

\section{REFERENCES}

[1] S. Selvan, P. Nair, U. Umayal, "A Review on Photo Voltaic MPPT Algorithms", International Journal of Electrical and Comuter Engineering, Vol. 6, No. 2, pp. 567-582, 2016

[2] F. D. Murdianto, O. Penangsang, A. Priyadi, "Modeling and Simulation of MPPT-Bidirectional Using Adaptive Neuro Fuzzy Inference System (ANFIS) in Distributed Energy Generation System", 2015 International Seminar on Intelligent Technology and Its Applications, Surabaya, Indonesia, May 20-21, 2015

[3] A. J. Sabzali, E. H. Ismail, H. M. Behbehani, "High voltage step-up integrated double Boost-Sepic DC-DC converter for fuel-cell and photovoltaic applications", 4th International Congress on Renewable Energy: Generation and Applications, Milwakee, USA, October 19-22, 2014

[4] A. Elgharbi, Ameliorated Control of a Motor-pump Coupled to a Photovoltaic Generator, MSc Thesis, Sciences Uuniversity of Tunis, 2010 (in French)

[5] D. Mezghani, Study of a Photovoltaic Pumping by a Bond Graph Approach, Sciences University of Tunis, 2009. (in French)

[6] Y. Oueslati, Study of Performance of a Photovoltaic Generator Coupled to the Network Draft, MSc Thesis, High School of Sciences and Techniques of Tunis, 2007 (in French)

[7] A. Nouaiti, A. Saad, A. Mesbahi, M. Khalfallah, M. Reddak, "Design and Test of a new Three-Phase Multilevel Inverter for PV System Applications", Engineering Technology \& Applied Science Research, Vol. 9, No. 1, pp. 3846-3851, 2019

[8] A. S. Saidi, M. Ben Slimene, M. A. Khlifi, "Transient Stability Analysis of Photovoltaic System with Experimental Shading Effects", Engineering Technology \& Applied Science Research, Vol. 8, No. 6, pp. 3592-3597, 2018

[9] S. Javadpoor, D. Nazarpour, "Modeling of PV-FC-Hydrogen Hybrid Power Generation System", Engineering Technology \& Applied Science Research, Vol. 7, No. 2, pp. 1455-1457, 2017

[10] Z. R. Labidi, H. Schulte, A. Mami, "A Systematic Controller Design for a Photovoltaic Generator with Boost converter using Integral State Feedback Control", Engineering Technology \& Applied Science Research, Vol. 9, No. 2, pp. 4030-4036, 2019

[11] D. Zhang, Designing a SEPIC Converter, Application Report 1484, Texas Instruments, 2013

[12] H. Othmani, H. Chaouali, D. Mezghani, A. Mami, "Design and building of sepie DC-DC converter devoted to Kaneka GSA-60 PV panels", 7th International Conference on Modelling, Identification and Control, Monastir, Tunisia, May 8-10, 2015

[13] D. Mezghani, H. Othmani, A. Mami, "Bond graph modeling and robust control of a photovoltaic generator that powered an induction motor pump via SEPIC converter”, Electrical Energy Systems, Vol. 29, No. 3, Article ID e2746, 2019

[14] A. Arora, P. Gaur, "Comparison of ANN and ANFIS based MPPT Controller for grid connected PV systems", Annual IEEE India Conference, New Delhi, India, December 17-20, 2015

[15] F. Bendary, E. M. Elsaied, W. A. Mohamed, Z. E. Afifi, "GeneticANFIS Hybrid Algorithm for Optimal Maximum Power Point Tracking of PV Systems", 17th International Middle East Power Systems Conference, Mansoura, Egypt, December 15-17, 2015 